\title{
PENGEMBANGAN MODUL BERBASIS DISCOVERY LEARNING PADA MATERI JARINGAN TUMBUHAN UNTUK MENINGKATKAN KEMAMPUAN LITERASI SAINS SISWA KELAS XI IPA SMA
}

\author{
Desi Ariana, Risya Pramana Situmorang, Agna Sulis Krave \\ Program Studi Pendidikan Biologi, Universitas Kristen Satya Wacana \\ E-mail: desiariana021295@gmail.com
}

DOI: dx.doi.org/10.26418/jpmipa.v11i1.31381

\begin{abstract}
This study aims to develop a module based on discovery learning in improving scientific literacy skills in the 11th grade of science class in senior high school. This study refers to the modified Borg and Gall model into 7 steps, (1) preliminary study; (2) planning; (3) preparation of modules; (4) expert judgment; (5) revisions; (6) limited trials; (7) revision II. The research samples are in XI MIPA 2 and XI MIPA class at 3 SMAN 1 Bringin. The technique of collecting data using written tests, questionnaires, and observations. Hypothesis testing to measure the increase in cognitive learning outcomes of students using an independent t-test on n-gain students. Assessments from material experts, subject matter teachers, colleagues, and high school students show that the modules that have been developing suitable for use in the learning process with an achievement level of $86 \%$, $95 \%, 88 \%$, and $90 \%$ respectively. The results of the t-test showed an increase in students' literacy skills ( $p$ <0.05) of 0.71 (high category). It can be concluded, the modules that have been developing become worthy to use in the learning process and effective in enhancing the scientific literacy skills of senior high school students in XI class.
\end{abstract}

Keywords: discovery learning, module, plant tissue-test

Abstrak

Penelitian ini bertujuan untuk mengembangkan modul berdasarkan discovery learning dalam meningkatkan keterampilan literasi sains di kelas XI MIPA di Sekolah Menengah Atas. Studi ini mengacu pada model Borg dan Gall yang dimodifikasi menjadi 7 langkah, (1) studi pendahuluan; (2) perencanaan; (3) persiapan modul; (4) penilaian ahli; (5) revisi; (6) uji coba terbatas; (7) revisi II. Sampel penelitian adalah kelas XI MIPA 2 dan XI MIPA di 3 SMAN 1 Bringin. Teknik pengumpulan data menggunakan tes tertulis, angket, dan observasi. Pengujian hipotesis untuk mengukur 
Vol. 11, No. 1 (2020) h. 34-46

peningkatan hasil belajar kognitif siswa menggunakan uji-t independen pada siswa n-gain. Penilaian dari ahli materi, guru materi pelajaran, kolega, dan siswa sekolah menengah menunjukkan bahwa modul yang telah dikembangkan cocok untuk digunakan dalam proses pembelajaran dengan tingkat pencapaian masing-masing $86 \%, 95 \%, 88 \%$, dan $90 \%$. Hasil uji-t menunjukkan peningkatan keterampilan baca tulis siswa $(\mathrm{p}<0,05)$ dari 0,71 (kategori tinggi). Dapat disimpulkan, modul yang telah dikembangkan menjadi layak untuk digunakan dalam proses pembelajaran dan efektif dalam meningkatkan keterampilan literasi ilmiah siswa SMA di kelas XI.

Kata Kunci: discovery learning, modul, uji jaringan tumbuhan

Perkembangan IPTEK pada era sekarang ini sangat pesat sehingga generasi muda perlu dibekali keterampilan hard skill dan soft skill yang memadai sesuai dengan kriteria abad ke-21 untuk mempersiapkan generasi yang berkualitas. Salah satu keterampilan yang penting untuk meningkatkan pengetahuan dan kemampuan menyelesaikan suatu masalah adalah literasi sains. Seseorang yang memiliki literasi sains mampu menggunakan konsep sains, mempunyai keterampilan proses sains untuk menilai dalam membuat keputusan sehari-hari saat berhubungan dengan orang lain, masyarakat dan lingkungannya. Merujuk data PISA (2015) dalam Iswadi (2018), performa siswa Indonesia dalam sains masih tergolong rendah. Sejalan dengan temuan PIRLS tahun 2006 yang menyatakan bahwa kompetensi literasi siswa Indonesia sangat rendah dan menempatkan Indonesia diperingkat 41 dari 45 negara yang disurvei.

Rendahnya pemahaman konsep sains sering dikaitkan pula dengan aktivitas pembelajaran yang masih berorientasi pada kegiatan menghafal (retensi), metode pembelajaran masih konvensional, dan tingkat kesukaran materi yang dipelajari oleh siswa. Oleh karena itu, agar siswa dapat memahami materi maka perlu dikaji secara spesifik.
Data dari Kemendikbud menunjukkan bahwa penguasaan beberapa materi untuk ujian nasional masih tergolong rendah. Salah satunya adalah materi mengenai jaringan tumbuhan. Data tersebut menunjukkan bahwa persentase penguasaan materi jaringan tumbuahan pada soal biologi Ujian Nasional SMA/MA tahun pelajaran 2016/2017 masih rendah yaitu $40 \%$ di tingkat nasional, 47,13 \% ditingkat Provinsi Jawa Tengah dan 56,42 \% di tingkat kabupaten/kota. Selain itu, pada materi ini terdapat banyak sekali hafalan dan terkadang siswa belum mengerti konsep dasarnya, sehingga pemahaman siswa mengenai materi ini menjadi kurang.

Memperhatikan kesulitan yang dirasakan oleh peserta didik, maka salah satu solusinya adalah dengan memvariasikan model atau metode pembelajaran yang mengarahkan peserta didik kepada pembelajaran yang membantu dalam pengembangan potensinya (pembelajaran bermakna). Pembelajaran yang bermakna menekankan pada keterlibatan aktif dan pemberian pengalaman langsung. Pembelajaran kontekstual salah satunya dapat dilakukan dengan model Discovery learning. Model ini menekankan pentingnya peserta didik bersikap ilmiah dan berperan aktif dalam menemukan konsep atau prinsip yang 
Vol. 11, No. 1 (2020) h. 34-46

sebelumnya belum mereka temukan secara mandiri. Hal ini sependapat dengan Joolingan et al. (2007); Uside et al. (2013) model discovery learning dapat meningkatkan penguasaan konsep dan pengetahuan siswa, Hofstein \& Wolberg (2005); Devi (2010); Ilmi et al. (2012); Mahmoud (2014) model discovery learning dapat mengembangkan keterampilan dan proses sains siswa. Menurut Akinbobola \& Afolabi (2010) dalam Prasetyana et al. (2016), penggunaan pendekatan discovery dapat melibatkan siswa dalam kegiatan pemecahan masalah, belajar mandiri, berpikir kritis, dan pemahaman serta belajar kreatif. Istiana et al. (2015), dalam penelitiannya juga menyatakan model pembelajaran discovery learning menuntut siswa untuk lebih aktif dalam menemukan konsep materi.

Selain itu, pengembangan bahan ajar seperti modul juga perlu dilakukan karena dapat memberi peluang bagi siswa untuk memahami aspek sains dan membantu siswa dalam mencapai tujuan belajar yang telah dirumuskan secara spesifik dan operasional. Beberapa hasil penelitian juga menunjukkan bahwa penggunaan modul pada proses pembelajaran dapat meningkatkan hasil pelajaran (Esmiyati et al., 2013; Dewi et al., 2014). Menurut Widyaningrum et al. (2014), dalam hasil penelitiannya menjelaskan bahwa penggunan modul berbasis model pembelajaran tertentu dapat meningkatkan hasil belajar siswa. Pembelajaran melalui modul memiliki tujuan utama yaitu supaya dapat meningkatkan efisiensi dan efektifitas pembelajaran di sekolah. Modul adalah salah satu bahan ajar cetak yang dirancang sehingga dapat dipelajari secara mandiri oleh peserta didik. Selain itu modul dapat digunakan untuk belajar secara mandiri karena di dalamnya dilengkapi dengan petunjuk sehingga kegiatan belajar dapat dilakukan tanpa kehadiran pengajar. Berdasarkan latar belakang masalah yang dikaji maka penelitian ini perlu dilakukanuntuk mengembangkan modul berbasis discovey learning dalam meningkatkan kemampuan literasi sains siswa kelas XI IPA SMA.

\section{METODE}

Desain yang dilakukan dalam penelitian ini adalah $\mathrm{R} \& \mathrm{D}$ (Research \& Development). Metode penelitian dan pengembangan bertujuan untuk mendapatkan suatu produk melalui proses pengujian keefektivan yang dikembangkan melalui beberapa aspek sebagai dasar melakukan proses perbaikan sampai menghasilkan produk yang layak pakai. Menurut Borg and Gall (1983), penelitian pengembangan berorientasi pada proses pengembangan dan validasi produk-produk yang digunakan dalam penelitian. Penelitian ini memiliki sepuluh langkah yang dikembangkan menurut teori, tetapi hanya tujuh langkah yang dilakukan oleh peneliti karena keterbatasan peneliti dalam hal waktu dan biaya. Pelaksanaan penelitian dan pengembangan ini dapat dihentikan jika telah dihasilkan draft final, tanpa pengujian hasil.

Prosedur pengembangan yang dilakukan meliputi 1) tahap studi pendahuluan; 2) tahap perencanaan; 3) tahap penyusunan $d r a f t ; 4)$ tahap validasi produk; 5) tahap revisi I; 6) tahap uji coba terbatas; 7) tahap revisi II. Pada tahap studi pendahuluan dilakukan survei lapangan dan studi pustaka. Pada tahap perencanaan dilakukan analisis tugas yang meliputi analisis struktur isi, analisis pemetaan materi, kompetensi, indikator dan analisis tujuan pembelajaran. Pada tahap penyusunan 
draft dilakukan penyusunan modul dan perangkat pendukungnya. Penelitian dan pengembangan modul mengadopsi buku teks SMA berbasis kurikulum 2013 yang disempurnakan. Pada tahap validasi produk dilakukan penilaian kelayakan terhadap modul oleh tiga orang dosen ahli, 2 orang guru biologi, dan 2 orang teman sejawat untuk mendapatkan penilaian dan saran perbaikan. Pada tahap revisi I, dilakukan analisis penilaian dari dosen ahli, guru, dan teman sejawat. Penilaian yang diberikan oleh validator berupa penilaian kualitatif terhadap produk yang kemudian dijadikan sebagai dasar untuk melakukan revisi I. Pada tahap uji coba terbatas, dilakukan uji coba modul hasil revisi I kepada siswa kelas IX SMA. Pada tahap revisi II, dilakukan revisi berdasarkan hasil uji coba terbatas sehingga dihasilkan draft III. Desain uji coba produk yang dilakukan meliputi uji coba ahli dan praktisi serta uji coba terbatas yang dilakukan hanya pada kelas XI IPA 3 SMAN 1 Bringin. Sementara uji coba keterbacaan produk dilakukan di SMAN 1 Bringin.

Tabel 1. Rancangan uji coba terbatas

\begin{tabular}{llll}
\hline Group & $\begin{array}{l}\text { Pre- } \\
\text { test }\end{array}$ & $\begin{array}{l}\text { Treat } \\
\text { ment }\end{array}$ & $\begin{array}{l}\text { Post } \\
\text {-test }\end{array}$ \\
\hline Eksperimen & $\mathrm{T} 1$ & $\mathrm{X}$ & $\mathrm{T} 2$ \\
\hline Kontrol & $\mathrm{T} 1$ & $\mathrm{Y}$ & $\mathrm{T} 2$ \\
\hline
\end{tabular}

Sumber : Sugiyono (2012)

\section{Keterangan :}

T1 : Tes kemampuan awal sebelum perlakuan

T2 : Tes kemampuan akhir setelah perlakuan

$\mathrm{X}$ : Perlakuan implementasi modul berbasis discovery learning

$\mathrm{Y}$ : Perlakuan implementasi tanpa modul berbasis discovery learning.
Penelitian ini dilaksanakan di SMAN 1 Bringin pada bulan AgustusDesember 2018 dengan subyek penelitian yaitu 30 orang siswa kelas XI IPA 3 sebagai kelas eksperimen dan kelas XI IPA 2 sebagai kelas kontrol. Teknik yang digunakan dalam penelitian pengembangan ini yaitu observasi, angket, dan tes tertulis. Instrumen yang digunakan dalam penelitian ini meliputi lembar penilaian modul, lembar observasi keterlaksanaan pembelajaran, lembar observasi literasi sains siswa, angket dan soal tes literasi. Teknik analisis data dalam penelitian ini meliputi :

1) Analisis hasil validasi perangkat dengan menggunakan rumus

Teknik analisis data terhadap data validasi modul berbasis discovery learning dilakukan langkah-langkah sebagai berikut :

a) Menghitung skor total dari setiap komponen yang dinilai oleh validator.

b) Menghitung skor total rata-rata dari setiap komponen yang dinilai oleh validator dengan menggunakan rumus :

$$
\bar{X}=\frac{\sum X}{n}
$$

Keterangan :

$$
\begin{aligned}
& \bar{X}=\text { Skor rata-rata } \\
& \sum X=\text { Total skor } \\
& n \quad=\quad \begin{array}{c}
\text { Jumlah Item dalam } \\
\text { komponen yang dinilai }
\end{array}
\end{aligned}
$$

2) Mengkonversi skor menggunakan kategorisasi

Kategorisasi skor penilaian dilakukan sebagai bentuk interpretasi dalam bentuk interval dan kategori. Kategorisasi skor penilaian modul oleh validator disajikan pada Tabel 2 . 
Vol. 11, No. 1 (2020) h. 34-46

Tabel 2. Kategorisasi skor penilaian modul oleh validator

\begin{tabular}{lll}
\hline Interval & Nilai & Kategori \\
\hline $\mathrm{X} \geq \mathrm{Yi}+1 . \mathrm{Sbi}$ & $\mathrm{A}$ & Sangat Baik \\
\hline $\mathrm{Yi}+1 . \mathrm{Sbi}>\mathrm{X} \geq \mathrm{Yi}$ & $\mathrm{B}$ & Baik \\
\hline $\mathrm{Yi}>\mathrm{X} \geq \mathrm{Yi}-1$. Sbi & $\mathrm{C}$ & Cukup \\
\hline $\mathrm{X}<\mathrm{Yi}-1$. Sbi & $\mathrm{D}$ & Tidak Baik \\
\hline
\end{tabular}

\section{Keterangan :}

$\mathrm{Yi}=$ Rerata skor ideal $=($ S.Maks ideal + S. Min ideal)

Simpangan baku ideal $(\mathrm{Sbi})=1 / 6$

(S.Maks ideal + S. Min ideal)

$\mathrm{X}=$ Perolehan skor

Skor maksimal ideal $=\Sigma$ butir kriteria $\mathrm{x}$ skor tertinggi

Skor terendah ideal $=\Sigma$ butir kriteria $\mathrm{x}$ skor terendah

3) Melakukan kriteria pengambilan keputusan

Kriteria pengambilan keputusan terhadap perbaikan produk menurut Akbar (2013) disajikan pada Tabel 3.

Tabel 3. Kriteria keputusan pengembangan perbaikan modul

\begin{tabular}{lll}
\hline $\begin{array}{l}\text { Tingkat } \\
\text { Pencapaian }\end{array}$ & Kualifikasi & Keterangan \\
\hline $90 \%-100 \%$ & Sangat baik & $\begin{array}{l}\text { Tidak perlu } \\
\text { direvisi }\end{array}$ \\
\hline $75 \%-89 \%$ & Baik & $\begin{array}{l}\text { Tidak perlu } \\
\text { direvisi }\end{array}$ \\
\hline $65 \%-74 \%$ & Cukup & Direvisi \\
\hline $55 \%-64 \%$ & $\begin{array}{l}\text { Kurang } \\
\text { baik }\end{array}$ & Direvisi \\
\hline $0 \%-54 \%$ & $\begin{array}{l}\text { Kurang } \\
\text { cukup }\end{array}$ & Direvisi \\
\hline
\end{tabular}

4) Analisis aspek konten literasi sains Analisis hasil belajar peserta didik digunakan metode gain ternormalisasi menurut Hake (2018) yaitu sebagai berikut :

$$
(\mathrm{n}-\text { gain })=\frac{T 2-T 1}{I s-T 1}
$$

\section{Keterangan:}

$\mathrm{T} 1=$ Nilai pretest

$\mathrm{T} 2=$ Nilai postest

Is $=$ Skor maksimal pretest atau postest

Perolehan gain ternomalisasi siswa kemudian dihitung rata-ratanya. Nilai gain rata-rata masing-masing siswa dikategorikan menurut Hake (2018).

Tabel 4. Kategorisasi perolehan gain skor siswa

\begin{tabular}{ll}
\hline Interval & Kategori \\
\hline$(\mathrm{g}) \geq 0,7$ & Tinggi \\
\hline $0,7>(\mathrm{g}>) \geq 0,3$ & Sedang \\
\hline$(\mathrm{g})<0,3$ & Rendah \\
\hline
\end{tabular}

5) Analisis efektivitas perangkat pembelajaran.

Analisis efektivitas analisis kuantitatif melalui uji kelas quasi eksperimen dengan uji t. Penggunaan teknik statistik uji $\mathrm{t}$ memerlukan prasyarat yang harus dipenuhi, antara lain normalitas data dan homogenitas. Uji normalitas data dilakukan untuk mengetahui kenormalan data dan untuk menentukan uji selanjutnya apakah menggunakan statistik parametrik atau non parametrik. Data dikatakan berdistribusi normal pada taraf signifikansi 5\% apabila harga probabilitas perhitungan lebih besar daripada 0,05. Uji homogenitas varians digunakan untuk mengetahui apakah sampel berasal dari populasi yang homogen atau tidak. Uji homogenitas yang dilakukan adalah uji homogenitas varian. Sampel penelitian dikatakan dapat berasal dari populasi yang homogen pada taraf signifikansi 5\% apabila harga probabilitas perhitungan lebih besar daripada 0,05. Nilai pretest dan postest akan diuji dengan Paired sampe t test untuk mengetahui ada 
tidaknya perbedaan sebelum dan setelah pemberian perlakukan. $\mathrm{N}$-gain skor kemampuan literasi sains peserta didik dianalisis dengan uji tmenggunakan program SPSS 18.0. $\mathrm{N}$-gain skor akan diuji dengan Independent sample $t$ test. Penerimaan atau penolakan $\mathrm{H} 0$ dapat dilihat melalui probabilitas (signifikansi) yaitu jika probabilitas > 0,05 maka H0 diterima, demikian sebaliknya jika probabilitas (signifikansi) $\leq 0,05$ maka $\mathrm{H0}$ ditolak. Dalam penelitian ini, data yang digunakan adalah $n$-gain skor nilai dimensi konten literasi sains siswa yang menggunakan modul berbasis discovery learning. Adapun hipotesis nol (H0) dan hipotesis alternatif (H1) dalam penelitian ini adalah:

$\mathrm{H} 0$ :Penerapan modul berbasis discovery learning pada materi jaringan tumbuhan tidak efektif meningkatkan kemampuan literasi sains siswa dalam aspek konten

H1:Penerapan modul berbasis discovery learning pada materi jaringan tumbuhan efektif meningkatkan kemampuan literasi sains siswa dalam aspek konten.

\section{HASIL DAN PEMBAHASAN Kelayakan Modul}

Hasil rekap angket menunjukkan bahwa modul berbasis discovery learning yang telah dikembangkan layak untuk digunakan dalam proses pembelajaran materi struktur dan jaringan tumbuhan. Rata-rata tingkat kelayakannya mencapai $>80 \%$ dengan kriteria baik. Modul berbasis discovery learning dalam penelitian ini telah dikembangkan melalui 6 langkah yaitu stimulasi, identifikasi masalah, pengumpulan data, pengolahan data, verifikasi dan generalisasi. Materi dalam modul mecakup tiga sub pokok bahasan, yaitu klasifikasi jaringan tumbuhan, organ pada tumbuhan dan sifat totipotensi serta aplikasinya dalam kultur jaringan. Modul juga telah diuji kelayakannya oleh dosen ahli materi dan guru SMA. Sedangkan uji keterbacaannya dilakukan oleh teman sejawat dan siswa kelas XI SMA. Validasi oleh ahli materi, guru SMA, teman sejawat dan siswa SMA memberikan rata-rata tingkat kelayakan modul masing-masing 86\%, 95\%, 88\% dan $90 \%$. Secara lebih terperinci, hasil rekap angket oleh para validator disajikan pada tabel berikut:

Tabel 5. Hasil valuasi kelayakan modul oleh para ahli materi, guru bidang studi biologi, teman sejawat dan siswa kelas

\begin{tabular}{|c|c|c|c|}
\hline \multicolumn{4}{|c|}{ XI SMA } \\
\hline No. & $\begin{array}{c}\text { Aspek } \\
\text { Penilaian }\end{array}$ & $(\%)$ & Kriteria \\
\hline \multicolumn{4}{|c|}{ A. Ahli Materi } \\
\hline 1 & Pendahuluan & 85 & Baik \\
\hline 2 & Pembelajaran & 88 & Baik \\
\hline 3 & Isi & 86 & Baik \\
\hline 4 & Tugas/Evaluasi & 87 & Baik \\
\hline \multirow[t]{2}{*}{5} & Rangkuman & 83 & Baik \\
\hline & Rata-rata* & 86 & Baik \\
\hline \multicolumn{4}{|c|}{ B. Guru Bidang Studi Biologi } \\
\hline 1 & Fisik & 95 & $\begin{array}{l}\text { Sangat } \\
\text { baik }\end{array}$ \\
\hline 2 & Pendahuluan & 94 & $\begin{array}{l}\text { Sangat } \\
\text { baik }\end{array}$ \\
\hline 3 & Pembelajaran & 90 & $\begin{array}{c}\text { Sangat } \\
\text { Baik }\end{array}$ \\
\hline 4 & Isi/Materi & 96 & $\begin{array}{c}\text { Sangat } \\
\text { baik }\end{array}$ \\
\hline 5 & Pemanfaatan & 93 & $\begin{array}{c}\text { Sangat } \\
\text { Baik }\end{array}$ \\
\hline 6 & Tugas/Evaluasi & 96 & $\begin{array}{c}\text { Sangat } \\
\text { baik }\end{array}$ \\
\hline
\end{tabular}


Jurnal Pendidikan Matematika dan IPA

Vol. 11, No. 1 (2020) h. 34-46

\begin{tabular}{|c|c|c|c|}
\hline 7 & Rangkuman & 98 & $\begin{array}{c}\text { Sangat } \\
\text { baik }\end{array}$ \\
\hline & Rata-rata* & 95 & $\begin{array}{c}\text { Sangat } \\
\text { baik }\end{array}$ \\
\hline \multicolumn{4}{|c|}{ C. Teman Sejawat } \\
\hline 1 & Fisik & 88 & Baik \\
\hline 2 & Pendahuluan & 90 & $\begin{array}{c}\text { Sangat } \\
\text { baik }\end{array}$ \\
\hline 3 & Isi/Uraian & 89 & Baik \\
\hline 4 & Tugas/Evaluasi & 88 & Baik \\
\hline \multirow[t]{2}{*}{5} & Rangkuman & 88 & Baik \\
\hline & Rata-rata* & 88 & Baik \\
\hline \multicolumn{4}{|c|}{ D. Siswa Kelas IX IPA SMA } \\
\hline 1 & Tampilan & 90 & $\begin{array}{c}\text { Sangat } \\
\text { baik }\end{array}$ \\
\hline 2 & $\begin{array}{l}\text { Penyajian } \\
\text { Materi }\end{array}$ & 91 & $\begin{array}{c}\text { Sangat } \\
\text { baik }\end{array}$ \\
\hline 3 & Manfaat & 89 & Baik \\
\hline & Rata-rata* & 90 & $\begin{array}{c}\text { Sangat } \\
\text { baik }\end{array}$ \\
\hline
\end{tabular}

penilaian menunjukkan bahwa modul yang dikembangkan layak digunakan dalam proses pembelajaran. Rata-rata aspek kelayakan yang diperoleh dari hasil analisis angket oleh ahli materi, guru bidang studi biologi, teman sejawat dan siswa SMA masing-masing sebesar $86 \%, 95 \%, 88 \%$ dan $90 \%$ dengan kriteria masing-masing baik dan sangat baik. Hasil perolehan kriteria layak ini sesuai dengan hasil penelitian yang dilakukan oleh Zainuddin et al. (2012); Izzati et al. (2013); Septianu et al. (2014) yang menyatakan bahwa setelah melalui tahap validasi, modul yang telah dikembangkan layak digunakan sebagai media pembelajaran dalam hal konten, penyajian dan kebahasaan. Meskipun tergolong" layak" di awal, modul yang dikembangkan tetap direvisi berdasarkan masukan dari ahli materi serta guru bidang studi biologi. Hal ini bertujuan untuk perbaikan dan penyempurnaan modul. Modul yang dikembangkan memiliki karakteristik khusus yaitu setiap kegiatannya sangat menekankan kerjasama kelompok serta diskusi dalam menemukan konsep. Hal ini sependapat dengan Budiono dan Susanto (2006) yang mengemukakan bahwa cara yang paling baik dalam menggunakan modul adalah siswa aktif mempelajarinya bersama dengan teman dalam kelompok, sementara guru melakukan pengecekan secara intensif dan memberikan bantuan kepada siswa yang kesulitan dalam mempelajari modul secara individual. Model pembelajaran dalam modul ini telah membantu siswa menjadi lebih memahami materi pelajaran melalui proses mengamati, menanya, mencoba, mengasosiasi dan mengkomunikasikan materi yang dipelajari. Model pembelajaran dalam modul discovery learning ini terbukti efektif pada kualifikasi validator adalah $\mathrm{S} 1$ atau S2 dalam bidang yang sesuai. Hasil 
pembelajaran materi jaringan tumbuhan. Hal tersebut dapat dilihat dari peningkatan hasil belajar kognitif siswa. Hasil penelitian ini sesuai dengan yang dilaporkan Purwanti et al. (2015) bahwa modul pembelajaran berbasis NTGD (Numbered Team in Guided Discovery) berhasil secara nyata dalam meningkatkan hasil belajar pada materi struktur tumbuhan. Wenning (2005) menyatakan bahwa metode discovery learning dapat membantu siswa mengembangkan suatu konsep berdasarkan pengalaman pertama yang diberikan oleh guru. Batubara (2014) dalam penelitiannya menyatakan bahwa strategi pembelajaran inkuiri maupun discovery dapat meningkatkan hasil belajar siswa pada materi bioteknologi. Julianto (2009), dalam hasil penelitiannya juga menyatakan bahwa penggunaan metode discovery-inquiry dapat meningkatkan kemampuan siswa tentang konsep hereditas. Tran (2014), menyimpulkan pembelajaran dengan model discovery learning lebih efektif daripada model pembelajaran tradisional. Uside et al. (2013) menyatakan bahwa pencapaian belajar siswa lebih signifikan dengan adanya metode discovery. Kemendikbud juga menyatakan bahwa belajar dengan discovery learning dapat membantu siswa untuk memperbaiki keterampilan dan proses kognitif siswa serta dapat membantu memperkuat konsep dirinya karena memperoleh kepercayaan dari orang lain.

Modul berbasis discovery learning juga mendukung kegiatan-kegiatan siswa dalam proses pembelajaran karena siswa terlibat aktif dalam melakukan percobaan atau mengumpulkan informasi serta mendiskusikan hasil pengamatan atau analisisnya dalam menarik kesimpulan, sehingga dalam pembelajaran terjadi proses konstruksi pengetahuan pada diri siswa (McHaney, 2012). Pembelajaran dengan menggunakan modul menjadikan siswa kelas eksperimen aktif melakukan kegiatan seperti yang dideskripsikan dalam modul sehingga siswa mampu menyusun konsep yang sesuai dengan teori yang ada. Selama proses pembelajaran berlangsung sebagian besar siswa mampu memahami makna dari percobaan yang telah dilakukan dengan bantuan modul berbasis discovery learning. Hal tersebut membantu siswa dalam menjawab soal postest yang diberikan dengan baik dan hasil belajar kognitif siswa meningkat. Pembelajaran dengan modul membuat siswa aktif, berfikir kreatif dan membantu siswa menemukan konsep. Hal ini sesuai dengan teori belajar Bruner dalam Budiningsih (2012), menyatakan bahwa proses belajar akan berjalan dengan baik jika guru memberikan kesempatan kepada siswa untuk menemukan konsep, teori, ataupun pemahaman melalui contohcontoh yang dijumpainya.

\section{Pengaruh Modul Terhadap Peningkatan Kemampuan Literasi Sains}

Penerapan modul berbasis discovery learning pada materi jaringan tumbuhan terbukti efektif dalam meningkatkan kemampuan literasi sains siswa ( $p<0.05$, Tabel 6). Dalam penelitian ini kemampuan literasi sains diukur berdasarkan hasil belajar kognitif siswa yang dievaluasi berdasarkan nilai pretest dan postest. Tabel 6 . menunjukkan bahwa peningkatan hasil belajar kognitif siswa pada kelompok eksperimen termasuk kategori tinggi (nilai $\mathrm{n}$-gain $=0.71$ dan gain $=42.20)$. Sedangkan peningkatan hasil belajar 
Jurnal Pendidikan Matematika dan IPA

Vol. 11, No. 1 (2020) h. 34-46

kognitif siswa pada kelompok kontrol dikategorikan sedang (nilai n-gain sebesar 0.60 dan gain $=35.80$ ). Rata-rata gain score pada kelompok eksperimen lebih besar dari pada kelompok kontrol.
Pada Tabel 6., dapat dilihat juga bahwa terdapat perbedaan hasil belajar yang signifikan sebelum dan setelah pemberian test pada kedua kelompok ( $\mathrm{p}$ $<0.05$, Tabel 6.)

Tabel 6. Pengaruh modul berbasis discovery learning terhadap hasil belajar siswa

\begin{tabular}{cccccccc}
\hline Kelompok & Pretest & Posttest & Gain \pm SD & $\begin{array}{c}N- \\
\text { gain }\end{array}$ & $\begin{array}{c}\text { Interpretasi } \\
\text { N-gain }\end{array}$ & Df & $\begin{array}{c}\text { Sig.(2- } \\
\text { tailed)* }\end{array}$ \\
\hline Kontrol & 42 & 78 & $35.80 \pm 3.17$ & 0.60 & Sedang & 29 & .00 \\
\hline Eksperimen & 40.67 & 82.87 & $42.20 \pm 3.02$ & 0.71 & Tinggi & 29 & .00 \\
\hline * uji paired sample t testpretest dan postest $(\mathrm{p}<0.05)$ & &
\end{tabular}

Penerapan modul berbasis discovery learning terbukti efektif meningkatkan kemampuan literasi sains. Hal tersebut dibuktikan dengan hasil belajar kognitif siswa menunjukkan peningkatan rata-rata nilai n-gain. Pembelajaran dengan modul berbasis discovery learning dapat meningkatkan aktivitas dalam pembelajaran, membuat siswa semakin bersemangat dalam belajar dan meningkatkan hasil belajar (Wahyudi, 2015). Hal tersebut relevan dengan hasil penelitian Handoko et al. (2016) yang menyatakan bahwa modul pembelajaran biologi berbasis discovery learning efektif dalam memberdayakan hasil belajar. Triyati et al. (2016), bahwa penerapan model pembelajaran discovery learning mampu meningkatkan hasil belajar biologi siswa SMA pada materi struktur dan jaringan tumbuhan pada siklus I sebesar $87.50 \%$ dan siklus II sebesar $97.50 \%$.

Pembelajaran dengan menggunakan modul berbasis discovery learning pada materi jaringan tumbuhan dapat membantu siswa dalam mencapai hasil belajar yang lebih baik. Modul ini memberikan dorongan dan rangsangan kepada siswa untuk mempelajari bahan pelajaran dan menyelesaikan tugas yang ada di dalam modul. Modul ini membuat siswa lebih senang dan termotivasi dalam belajar sehingga hasil belajar siswa meningkat. Pembelajaran di dalam kelas berjalan dengan sangat terarah sesuai dengan tahapan pada modul. Modul ini sudah mengarah pada suatu tujuan belajar tuntas dan modul memuat petunjuk tentang apa yang harus dilakukan siswa dalam pembelajaran menggunakan modul. Materi pelajaran dalam modul juga disusun dalam suatu kerangka yang memperlihatkan kaitan dan urutan dalam bagian-bagiannya sehingga memudahkan siswa untuk mempelajarinya. Selain itu proses belajar mengajar dengan menggunakan modul, interaksi antara guru dan siswa berjalan dengan baik, hal ini dapat dilihat dari keaktifan siswa untuk bertanya kepada guru jika ada hal yang belum dimengerti.

\section{SIMPULAN DAN SARAN}

Modul pembelajaran berbasis dicovery learning pada materi jaringan tumbuhan yang dikembangkan memenuhi kategori baik sehingga layak digunakan dalam proses pembelajaran biologi. Penggunaan modul berbasis discovery learning pada materi jaringan tumbuhan dalam pembelajaran juga dapat meningkatkan kemampuan literasi sains kelas XI MIPA SMA pada dimensi konten dengan kategori tinggi. 


\section{SARAN}

Peneliti lain dalam mengembangkan model penemuan pada materi-materi pelajaran lain, menggunakan sampel yang lebih besar, dengan tujuan memperkecil kesalahan dan mendapatkan generalisasi yang lebih akurat. Selain itu, perlu diperhatikan alokasi waktunya, sehingga guru dapat mengelola waktu sesuai dengan perencanaan.

\section{DAFTAR PUSTAKA}

Akbar, S. (2013). Instrumen Perangkat Pembelajaran. Bandung: Remaja Ro, W. (2002). Konsep Penelitian Pengembangan dalam Bidang Pendidikan dan Pembelajaran. Malang: Universitas Negeri Malang.

Batubara, A. E. (2014). Pengaruh Strategi Pembelajaran Inkuiri dan Discovery Terhadap Kemampuan Berpikir Kritis dan Hasil Belajar Biologi Siswa pada Topik Bioteknologi di MAN 1 Padangsidimpuan. Tesis Program Pascasarjana Universitas Negeri Medan. Medan.

Borg, W. R., \& Gall, M.D. (1983). Educational Research. New York London: Longman.

Budiningsih, A. (2012). Belajar dan Pembelajaran. Jakarta: PT Rineka Cipta.

Budiono, E., \& Susanto, H. (2006). Penyusunan dan Penggunaan Modul Pembelajaran Berdasar Kurikulum Berbasis Kompetensi Sub Pokok Bahasa Analisa Kuantitatif untuk Soal-Soal Dinamika Sederhana pada Kelas X
Semester I SMA. Jurnal Pendidikan Fisika Indonesia, Vol.1, No.2,79-87. Diambil dari https://journal.unnes.ac.id/nju/ind ex.php/JPFI/article/view/166.

Devi, K. (2010). Implementasi Metode Guided Discovery dalam Pembelajaran Matematika untuk Meningkatkan Aktivitas dan Hasil Belajar Siswa Kelas IXB SMP N 1 Punung Kabupaten Pacitan. Skripsi. UNY.

Dewi, A. P., Sarwanto, \& Prayitno, B. A. (2014). Pengembangan Modul IPA Terpadu Untuk SMP/MTs Berbasis Eksperimen Pada Tema Fotosintesis Untuk Memberdayakan Keterampilan Proses Sains. Jurnal Inkuiri, Vol. 3, No.3, 30-40. Diambil dari https://media.neliti.com/media/pu blications/65789-ID-none.pdf

Esmiyati, Haryani, S., \& Purwantoyo, E. (2013). Pengembangan Modul IPA Terpadu Bervisi SETS (Science, Environment, Technology, And Society) Pada Tema Ekosistem. Unnes Science Education Journal,Vol.2,No.1,180-187.

Diambil dari https://journal.unnes.ac.id/sju/inde x.php/usej/article/view/1821

Istiana, G. A., Catur, A. N. S., \& Sukarddjo, J. (2015). Penerapan Model Pembelajaran Discovery Learning untuk Meningkatkan Aktivitas dan Prestasi Belajar Pokok Bahasan Larutan Penyangga pada Siswa Kelas XI IPA Semester II SMA Negeri I Ngemplak Tahun Pelajaran 2013/2014. Jurnal Pendidikan 
Kimia, Vol.4, No.2, 65-73. Diambil dari

https://jurnal.fkip.uns.ac.id/index. php/kimia

Iswadi, H. (2018). Sekelumit Dari Hasil PISA 2015 Yang Baru Dirilis. Diambil pada tanggal 19 Mei 2018, dari http://www.ubaya.ac.id/2014/cont ent/articles_detail/230/SekelumitDari-Hasil-PISA-2015-YangBaru-Dirilis.html.

Hake, R. R. (2018). Design-Based Research In Physics Education. Diambil pada tanggal 8 Juni 2018, dari

http://www.physics.indiana.edu/ hake/DBR Physics3.pdf

Handoko, A., Sajidan, \& Maridi. (2016). Pengembangan Modul Biologi Berbasis Discovery learning (Part of Inquiry Spectrum LearningWennig) Pada Materi Bioteknologi Kelas XII IPA Di SMA Negeri 1 Magelang Tahun Ajaran 2014/2015. Jurnal Inkuiri, Vol.5, No.3,144-154. Diambil dari https://media.neliti.com/media/pu blications/65303-IDpengembangan-modul-biologiberbasis-disc.pdf.

Hofstein \& Wolberg. (2005). Developing students ability to ask more and better question resulting inquiry type chemistry laboratories. Journal of Science Teaching, Vol.42, No.7, 791-806. Diambil dari https://onlinelibrary.wiley.com/do i/pdf/10.1002/tea.20072
Ilmi, Abrari, N. A., Indrowati, Meti, \& Probosari, R. M. (2012). Pengaruh Penerapan Metode Pembelajaran Guided Discovery Terhadap Keterampilan Proses Sains Siswa Kelas X SMA Negeri 1 Teras Boyolali Tahun Pelajaran 2011/2012. J. Pendidikan Biologi UNS, Vol 4, No.2, 44-52. Diambil dari

https://jurnal.uns.ac.id/bio/article/ view/5562.

Izzati, N, Hindarto, N, dan Pamelasari, S. D. (2013). Pengembangan Modul Tematik dan Inovatif Berkarakter Pada Tema Pencemaran Lingkungan Untuk Siswa Kelas VII SMP. Jurnal Pendidikan IPA Indonesia, Vol.2,No.2,183-188.

Diambil dari https://journal.unnes.ac.id/nju/ind ex.php/jpii/article/view/2721/2785

Joolingan, W. V. (2007). Cognitive tools forDiscovery learning. International Journal of Artificial Intelegence in Education (IJAIED). 1998. Vol.10, 385-397. Diambil dari https://telearn.archivesouvertes.fr/hal00197349/document

Julianto, T. (2009). Improving Knowledge of Heredity Concept Using Discovery-Inquiry Metrod: an Example of Class-Room Action Research. International Journal for Educational Studies. Vol. 1, No.2, 187-194.Diambil dari http://journals.mindamas.com/ind ex.php/educare/article/view/201. 
Mahmoud, A. K. A. (2014). The Effect of Using Discovery learning Strategi in Teaching Grammatical Rules to First Yaer General Secondary Student on Developing Their Achievemant and Metacognitive Skills. International Journal of Innovation and Scientific Research (IJISR, Vol. 2,No.2,146153.Diambil dari http://citeseerx.ist.psu.edu/viewdo c/download?doi=10.1.1.680.7755 \&rep $=$ rep $1 \&$ type $=p d f$

McHaney, R. W. (2012). Knowledge Spaces for Online Discovery learning. USA: Constructing SelfDiscovery learning Spaces Online.

Prasetyana, S. D., Sajidan \& Maridi.(2015). Pengembangan Model Pembelajaran Discovery Learning yang diintegrasikan dengan Group Investigation pada Materi Protista Kelas X SMA Negeri Karangpandan. Jurnal Inkuiri,Vol.4, No.4, 135-148. Diambil dari http://jurnal.fkip.uns.ac.id/index.p hp/sains.

Purwanti, E., Sajidan, \& Prayitno, A. B. (2015). Pengembangan dan Implementasi Modul Pembelajaran Berbasis Numbered Team In Guided Discovery (NTGD) Pada Materi Struktur Tumbuhan dan Pemanfaatannya dalam Teknologi di SMPN 4 Karanganyar. Jurnal Ikuiri, Vol., No.4,121-128. Diambil dari https://media.neliti.com/media/pu blications/68013-IDpengembangan-danimplementasi-modul-pemb.pdf.
Sawitri, D. W., Ambarwati, R., \& Wisanti. (2014). Pengembangan Modul Keanekaragaman Hayati Berbasis Pendekatan Saintifik Untuk Siswa Kelas X SMA. BioEdu Berkala Ilmiah Pendidikan Biologi, Vol.3, No.3. Diambil dari http://jurnalmahasiswa.unesa.ac.id index.php/bioedu/article/view/95 $\underline{51}$.

Septianu, Edo, Sindarmin dan Widiyatmoko, Arif. (2014). Pengembangan Modul IPA Terpadu Tema Perubahan Zat Berbasis Discovery Untuk Meningkatkan Keterampilan Generik dan Hasil Belajar Siswa. Unne Science Education Journal (USEJ). Vol 3, No3, 53-661. Diambil dari https://journal.unnes.ac.id/sju/inde x.php/usej/article/view/4283.

Tran, T. (2014). Discovery Learning with the Help of the Geogebra Dynamic Geometry Software. International Journal of Learning, Teaching and Educational Research (IJLTER). Vol. 7,No.1, 44-57. Diambil dari https://www.ijlter.org/index.php/ij lter/article/view/120

Triyati, U. S. U., Syamswisna, \& Yokhebed. (2016). Meningkatkan Hasil Belajar Pada Materi Struktur dan Fungsi Jaringan Tumbuhan Dengan Model Discovery. Jurnal Pendidikan Indonesia, Vol. 5, No. 2. Diambil dari http://jurnal.untan.ac.id/index.php /jpdpb/article/view/13674. 
Uside, Otiende Noel. Barcbok, K. H. \& Abura, O.(2013). Effect of Discovery Method on Secondary School Student's Achievment in Physics in Kenya. Asian Journal of Social Sciences and Humanities (AJSSH).Vol 2, No.3,351358.Diambil dari https://pdfs.semanticscholar.org/7 83d/98e09f854593333e44ad7cd2 93e06b3eb3d7.pdf

Wahyudi, E. (2015). Penerapan Discovery learning dalam Pembelajaran IPA Sebagai Upaya untuk Meningkatkan Hasil Belajar Siswa Kelas IX I di SMP Negeri 1 Kalianget. LENSA (Lentera Sains). Jurnal Pendidikan IPA, Vol.5, No.1. Diambil dari http://artikel.dikti.go.id/pelatihan/i ndex.php/pojs04/article/view/571.

Wenning, C. J. (2005). Levels of Inquiry: hierarchies of Pedagogical Practices and Inquiry Processes. Journal of Phisics
Theacher Education Online, Vol.2, No.3, 3-11. Diambil dari http://citeseerx.ist.psu.edu/viewdo c/download?doi=10.1.1.583.2818 $\&$ rep $=$ rep $1 \&$ type $=$ pdf.

Widyaningrum, Tri, Sarwanto, dan Puguh. (2014). Pengembangan Modul Berorientasi Poe (Predict, Observe, Explain) Pada Materi Pencemaran Untuk Meningkatkan Hasil Belajar Siswa. Jurnal Inkuiri. Vol. 3, No.2,249-258. Diambil dari https://jurnal.uns.ac.id/bioedukasi/ article/view/3920/3394.

Zainuddin, Mustikawati, \& Suyidno. 2012. Pengembangan Modul Fisika Bumi-Antariksa untuk Meningkatkan Prestasi Belajar Mahasiswa Prodi Pendidikan Fisika FKIP Unlam. Jurnal Vidya Karya, Vol. 1, No.1, 63-70. Diambil dari https://ppjp.ulm.ac.id/journal/inde x.php/JVK/article/view/974. 